\title{
PENERAPAN PEMBELAJARAN KOOPERATIF NUMBERED HEADS TOGETHER UNTUK MENINGKATKAN MOTIVASI DAN PRESTASI BELAJAR AKUNTANSI SISWA
}

\section{THE IMPLEMENTATION OF COOPERATIVE LEARNING "NUMBERED HEADS TOGETHER” MODEL TO INCREASE STUDENTS' MOTIVATION AND LEARNING ACHIEVEMENT IN ACCOUNTING SUBJECT}

\author{
Oleh: \\ Daniati \\ Prodi Pendidikan Akuntansi Universitas Negeri Yogyakarta \\ daniatisetia@yahoo.co.id \\ Sukanti, M.Pd. \\ Staf Pengajar Jurusan P. Akuntansi Universitas Negeri Yogyakarta
}

\begin{abstract}
Abstrak
Penelitian ini merupakan Penelitian Tindakan Kelas yang bertujuan meningkatkan Motivasi dan Prestasi Belajar Akuntansi Siswa Kelas X Akuntansi 1 SMKN 1 Yogyakarta Tahun Ajaran 2013/2014 melalui Penerapan Model Pembelajaran Kooperatif Tipe Numbered Heads Together. Pengumpulan data dalam penelitian ini dilakukan dengan menggunakan observasi partisipan, angket, dan tes yang dianalisis menggunakan deskriptif kuantitatif dengan persentase. Berdasarkan hasil penelitian disimpulkan bahwa terdapat peningkatan persentase skor Motivasi Belajar Akuntansi yang didapat melalui observasi sebesar $78,46 \%$ pada siklus I kemudian meningkat menjadi $83,93 \%$ pada siklus II atau terjadi peningkatan sebesar 5,47\%. Berdasarkan angket yang didistribusikan juga terjadi peningkatan skor Motivasi Belajar Akuntansi sebesar 3,12\% dimana skor pada siklus I sebesar 78,31\% meningkat menjadi 81,43\% pada siklus II. Terdapat peningkatan Prestasi Belajar Akuntansi dari siklus I ke siklus II yang dilihat dari peningkatan post test sebesar 13,96 serta naiknya persentase siswa yang mencapai KKM dari $71,43 \%$ pada siklus I meningkat pada siklus II menjadi $100 \%$.
\end{abstract}

Kata kunci: Numbered Heads Together, Motivasi dan Prestasi Belajar Akuntansi

\begin{abstract}
The research is a Classroom Action Research that aimed to improve students' motivation and learning achievement of X Accounting 1 SMKN 1 Yogyakarta year 2013/2014 through the Implementation of Cooperative Learning's "Numbered Heads Together" model._The data collection in this research was performed by using participant observation, questionnaires, and tests which were analyzed using the descriptive quantitative percentage. Based on the research findings, it can be concluded that there is a significant increase in the score of accounting learning motivation which were gained through observation, i.e. $78.46 \%$ in the first cycle. This score then increased $5.47 \%$ to $83.93 \%$ in the second cycle. Based on the questionnaire analysis result, there is a significant increase, i.e. $3.12 \%$ on the accounting learning motivation score from the first cycle to the second cycle (i.e. from $78.31 \%$ to $81.43 \%$ ). There is a significant learning achievement score increase from the first to second cycle which can be seen from the increase in the post-test score (13.96\%) as well as the increase in achieving the minimum passing criteria (KKM), from $71.43 \%$ in the first cycle to $100 \%$ in the second cycle.
\end{abstract}

Keywords: Numbered Heads Together, Motivation and Learning Achievement in Accounting 


\section{PENDAHULUAN}

Pendidikan memiliki peranan penting di dalam kehidupan dan kemajuan manusia. Menurut Dwi Siswoyo (2008: 18), secara teknis pendidikan adalah proses di mana masyarakat melalui lembagalembaga pendidikan (sekolah, perguruan tinggi, atau lembaga-lembaga lain) dengan sengaja mentransformasikan warisan budayanya, yaitu pengetahuan, nilai-nilai, dan keterampilan-keterampilan dari generasi ke generasi. Sekolah sebagai salah satu lembaga pendidikan memiliki fungsi untuk membentuk siswa sehingga bermanfaat bagi masyarakat. Pendidikan dapat diwujudkan dalam proses belajar mengajar yang menimbulkan interaksi di antara dua unsur yaitu siswa dan guru.

Proses pembelajaran merupakan suatu sistem yang bertujuan untuk meningkatkan kualitas pendidikan. Begitu banyak komponen yang dapat mempengaruhi proses pembelajaran. Namun demikian, seperti yang diungkapkan Wina Sanjaya (2012: 13) bahwa komponen yang selama ini dianggap sangat mempengaruhi proses pembelajaran adalah komponen guru. Hal ini memang wajar, sebab guru merupakan ujung tombak yang berhubungan langsung dengan siswa sebagai subjek dan objek belajar". Model pembelajaran merupakan salah satu cara yang digunakan guru untuk meningkatkan motivasi belajar, sikap belajar di kalangan siswa, mampu berpikir kritis, memiliki keterampilan sosial, dan pencapaian hasil pembelajaran yang lebih optimal.

Penggunaan metode yang kurang sesuai dengan tujuan pengajaran akan menjadi kendala dalam mencapai tujuan yang telah dirumuskan. Berdasarkan hasil observasi yang dilaksanakan di SMK Negeri 1 Yogyakarta, pembelajaran yang dilaksanakan belum banyak variasi, yaitu banyaknya intensitas ceramah dan latihan soal dalam pembelajaran. Guru sebagai salah satu sumber belajar berkewajiban menyediakan lingkungan belajar yang kreatif bagi kegiatan belajar anak didik di kelas sehingga akan mampu memberikan motivasi bagi siswanya untuk mengikuti pembelajaran dengan penuh semangat khususnya pada mata pelajaran akuntansi.

Sardiman A.M. (2011: 75) mendefinisikan motivasi belajar adalah keseluruhan daya penggerak di dalam diri siswa yang menimbulkan kegiatan belajar, yang menjamin kelangsungan dari kegiatan belajar dan yang memberikan arah pada kegiatan belajar, sehingga tujuan yang dikehendaki oleh subjek belajar itu dapat tercapai. Motivasi belajar akuntansi merupakan dorongan yang timbul dari diri siswa untuk menambah pengetahuannya tentang kegiatan pencatatan hingga penganalisaan data keuangan yang bertujuan untuk menyajikan informasi keuangan untuk para pengguna informasi tersebut. Motivasi belajar dapat timbul karena faktor interinsik, berupa hasrat dan keinginan dan dorongan belajar, harapan akan cita-cita. Sedangkan faktor eksterinsik adalah penghargaan, lingkungan belajar yang kondusif, dan kegiatan belajar yang menarik. Tetapi harus diingat, kedua faktor tersebut disebabkan oleh rangsangan tertentu, sehingga seseorang berkeinginan untuk melakukan aktivitas belajar yang lebih giat dan semangat.

Kualitas pendidikan di sekolah pada umumnya dapat dilihat dari prestasi belajar siswa. Prestasi belajar siswa juga dapat dijadikan pengukur pemahaman dan pengetahuan siswa terhadap suatu mata pelajaran. Dimyati (2009: 200) mengartikan prestasi belajar sebagai tingkat keberhasilan yang dicapai oleh siswa setelah mengikuti suatu kegiatan pembelajaran, di mana tingkat keberhasilan tersebut kemudian ditandai dengan skala nilai berupa huruf atau kata atau symbol. Selain itu, keberhasilan seorang guru dalam mengajar dapat diukur dengan prestasi belajar siswa. Menurut 
Muhibbin Syah (2012: 145-157) secara global, faktor-faktor yang mempengaruhi belajar siswa dapat dibedakan menjadi 3 macam, yakni faktor internal, eksternal, dan pendekatan belajar. Faktor internal meliputi (1) aspek psikologis, misalnya tingkat kecerdasan, sikap, bakat, motivasi, minat dan (2) aspek fisiologis yang meliputi kondisi fisik, kesehatan jasmani dan kondisi panca indera. Faktor eksternal meliputi lingkungan sosial dan non social, sedangkan faktor pendekatan belajar, misalnya strategi dan metode yang digunakan dalam pembelajaran.

$$
\text { Pembelajaran yang dapat }
$$

menumbuhkan motivasi siswa selama proses pembelajaran dan mampu meningkatkan prestasi belajar siswa adalah model yang menggunakan pendekatan Pembelajaran Kooperatif. Salah satu model pembelajaran kooperatif yaitu Numbered Heads Together (NHT) . Tipe ini memberikan kesempatan siswa untuk bekerja sama dengan kelompoknya di mana peserta didik akan diberi nomor. Dengan penggunaan tipe ini siswa akan lebih banyak beraktivitas dan siswa juga bisa berdiskusi dan sharing dengan teman sekelompoknya. Hal ini senada dengan penelitian yang dilakukan Russ Frank, bahwa pembelajaran kooperatif tipe Numbered Heads Together (NHT) memberikan keterlibatan total semua siswa, serta meningkatkan tanggung jawab individual dalam berkelompok (Mohamad Nur, 2005: 78). Dengan demikian melalui pembelajaran ini diharapkan mampu meningkatkan motivasi siwa untuk belajar dan mampu meningkatkan prestasi belajar siswa.

Berdasarkan pengamatan terhadap proses pembelajaran yang dilakukan peneliti dan juga melalui wawancara dengan guru mata pelajaran di kelas $\mathrm{X}$ Akuntansi 1 SMK Negeri 1 Yogyakarta tahun ajaran 2013/2014, terdapat siswa memiliki motivasi rendah dalam belajar. Terlihat ketika guru memberikan pekerjaan rumah (PR), masih terdapat 20 siswa atau
$64,52 \%$ yang mengerjakan di kelas dan menyalin jawaban teman. Ketika guru masuk kelas, siswa tidak segera mempersiapkan perlengkapan belajar, hanya terdapat 10 siswa atau 32,26\% yang sudah mempersiapkan buku pelajaran di atas mejanya, sisanya sebanyak 21 siswa atau $67,74 \%$ yang terlihat masih mengobrol dengan teman sebangku maupun teman yang duduk di depan atau belakangnya. Terdapat 18 siswa atau $58,07 \%$ yang tidak memperhatikan ketika guru menjelaskan dan ketika ada siswa lain yang mengerjakan soal di depan kelas. Hanya 11 siswa atau $35,48 \%$ yang bertanya tentang materi pelajaran, sisanya sebanyak 20 siswa atau 64,52\% masih belum aktif bertanya maupun mengeluarkan pendapat. Terdapat 10 siswa atau $32,26 \%$ yang tidak mengerjakan secara mandiri tugas yang diberikan guru di kelas. Dan sekitar 25 siswa atau $80,65 \%$ menunda-nunda saat diminta untuk mengumpulkan tugas.

Selain berimbas pada motivasi, penggunaan metode yang kurang tepat juga akan berimbas pada prestasi belajar siswa. Berdasarkan hasil observasi yang dilakukan peneliti di kelas X Akuntansi 1, masih terdapat 13 orang siswa atau $41,94 \%$ yang nilainya masih di bawah Kriteria Ketuntasan Minimal sebesar 75. Data ini diambil dari nilai ulangan harian pada materi Mengelola Dokumen Transaksi. Pola penyebaran tempat duduk siswa juga belum tertata dengan baik karena terdapat satu barisan yang hanya terdiri 2 siswa.

Sesuai dengan analisis situasi yang telah disebutkan, peneliti bermaksud melakukan penelitian dengan judul "Penerapan Model Pembelajaran Kooperatif Tipe Numbered Heads Together (NHT) untuk Meningkatkan Motivasi dan Prestasi Belajar Akuntansi Siswa Kelas X Akuntansi 1 SMK Negeri 1 Yogyakarta Tahun Ajaran 2013/2014". Tujuan dari penelitian ini adalah untuk meningkatkan Motivasi dan Prestasi 
Belajar Akuntansi melalui penerapan model pembelajaran kooperatif tipe Numbered Heads Together.

\section{METODE PENELITIAN}

\section{Desain Penelitian}

Penelitian ini merupakan penelitian tindakan kelas (Classroom Action Research) yang bersifat kolaboratif antara peneliti dengan guru mata pelajaran Akuntansi SMK Negeri 1 Yogyakarta. Menurut Rochiati Wiriaatmadja (2006: 13) penelitian tindakan kelas adalah bagaimana guru dapat mengorganisasikan kondisi praktik pembelajaran mereka, dan belajar dari pengalaman mereka sendiri di dalam kelas.Penelitian ini menggunakan model penelitian tindakan dari Kemmis dan Teggart, yaitu bentuk spiral dari siklus yang satu ke siklus berikutnya. Setiap siklus meliputi planning (rencana), action (tindakan), observation (pengamatan), dan reflection (refleksi).

\section{Tempat dan Waktu Penelitian}

Penelitian ini dilaksanakan di kelas $\mathrm{X}$ Akuntansi 1 SMK Negeri 1 Yogyakarta yang beralamat di Jalan Kemetiran Kidul No. 35 Pringgokusuman, Gedongtengen, Yogyakarta. Adapun waktu penelitian ini dilaksanakan pada semester gasal bulan September tahun ajaran 2013/2014.

\section{Subjek Penelitian}

Subjek penelitian ini adalah siswa kelas X Akuntansi 1 SMK Negeri 1 Yogyakarta Tahun Ajaran 2013/2014 yang berjumlah 28 siswa.

\section{Prosedur Penelitian}

Penelitian ini dilakukan secara kolaboratif dengan guru mata pelajaran Akuntansi SMK Negeri 1 Yogyakarta.
Penelitian ini dilaksanakan sebanyak dua siklus yang terdiri dari 8 tahapan yaitu perencanaan pertama, tindakan pertama, pengamatan pertama, refleksi pertama, revisi terhadap perencanaan pertama, tindakan kedua, pengamatan kedua, dan refleksi kedua.

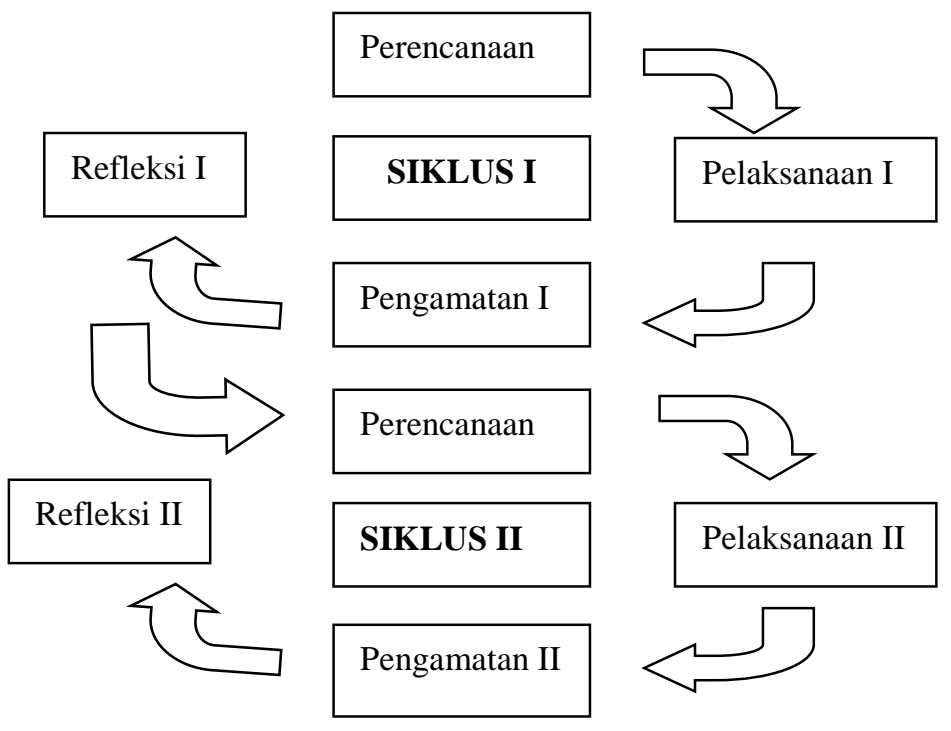

Gambar 1. Proses Penelitian Tindakan Suharsimi Arikunto, dkk (2012: 16)

\section{Data, Intrumen, dan Teknik Pengumpulan}

\section{a. Data}

Jenis data yang diperoleh dari observasi, angket, dan tes merupakan data kuantitatif. Teknik pengumpulan data dalam penelitian ini dilakukan dengan menggunakan observasi partisipan, angket, dan tes. Instrumen penelitian yang digunakan adalah lembar observasi, angket, dan tes. Observasi dan angket digunakan untuk memperoleh data peningkatan Motivasi Belajar Akuntansi siswa. Angket didistribusikan kepada siswa setiap siklus pada akhir pembelajaran. Adapun tes digunakan untuk memperoleh data peningkatan Prestasi Belajar Akuntansi siswa. Pre test dilakukan setiap akan memulai penyajian materi baru pada tiap siklus. Tujuannya 
adalah untuk mengidentifikasi taraf pengetahuan siswa mengenai bahan yang akan disajikan. Sedangkan post test adalah kegiatan evaluasi yang dilakukan guru setiap akhir penyajian materi pada tiap siklus. Tujuannya adalah untuk mengetahui taraf penguasaan siswa atas materi yang telah diajarkan.

\section{b. Teknik Analisis Data}

Teknik analisis data yang digunakan dalam penelitian ini adalah analisis data deskriptif kuantitatif dengan persentase. Dalam penelitian ini, data yang diperoleh dari hasil observasi, angket, dan tes adalah data kuantitatif, yang menunjukkan penilaian atas kemunculan kegiatan yang mencerminkan Motivasi dan Prestasi Belajar Akuntansi dengan kriteria yang telah ditentukan. Data yang diperoleh selanjutnya akan dianalisis untuk mengetahui persentase skor Motivasi Belajar Akuntansi siswa sebagai berikut (Sugiyono, 2012: 144):

1) Menentukan kriteria pemberian skor terhadap masing-masing indikator pada setiap aspek motivasi yang diamati.

2) Menjumlahkan skor untuk masingmasing aspek motivasi yang diamati.

3) Menghitung skor motivasi pada setiap aspek yang diamati dengan rumus:

$$
\%=\frac{\text { Skor Hasil Motivasi Siswa }}{\text { Skor Maksimum }} \mathrm{x}
$$

Sedangkan untuk menghitung peningkatan Prestasi Belajar Akuntansi siswa digunakan rumus sebagai berikut:

$$
M e=\frac{\sum x i}{N}
$$

(Sugiyono, 2012: 49)

Keterangan :

$\mathrm{Me} \quad$ : Rata-rata (mean)

$\sum x i \quad$ Jumlah semua nilai
$N \quad$ : Jumlah individu

\section{Indikator Keberhasilan}

Indikator keberhasilan tindakan ini adalah apabila setelah penerapan pembelajaran tipe Numbered Heads Together terjadi peningkatan motivasi belajar dan prestasi belajar akuntansi baik secara individu maupun kelas. Peningkatan motivasi belajar dihitung berdasarkan hasil observasi dengan indikator-indikator motivasi belajar yaitu: tekun menghadapi tugas, ulet menghadapi kesulitan, memiliki minat terhadap pelajaran, lebih senang belajar mandiri, cepat bosan pada tugastugas rutin, dapat mempertahankan pendapatnya, tidak mudah melepaskan halhal yang diyakininya serta senang mencari dan memecahkan masalah. Tindakan ini dinyatakan berhasil sekurang-kurangnya diperoleh persentase Motivasi Belajar Akuntansi yaitu $75 \%$.

Indikator keberhasilan Prestasi Belajar adalah adanya peningkatan prestasi belajar siswa dalam pembelajaran akuntansi yang dapat dililhat dari peningkatan nilai tes pada siklus I dan siklus II. Untuk melihat keberhasilan tindakan dapat dilihat adanya peningkatan nilai baik secara individu maupun nilai rata-rata kelas dari siklus sebelumnya. Apabila hasil tindakan tersebut mengalami kenaikan pada siklus I dan siklus II yang dilihat dari nilai post test, serta naiknya persentase siswa yang mencapai KKM sebesar 75 maka tindakan dinyatakan berhasil. 


\section{HASIL PENELITIAN DAN PEMBAHASAN}

\section{Motivasi Belajar Akuntansi}

\section{a. Indikator tekun menghadapi tugas}

Terjadi peningkatan pada siklus I ke siklus II sebesar 2,68\%. Peningkatan skor Motivasi Belajar Akuntansi siswa juga ditunjukkan dari data angket di mana terjadi peningkatan sebesar $0,9 \%$ dari siklus I ke siklus II. Pada data angket kenaikan skor indikator tekun menghadapi tugas hanya $0,9 \%$. Walau demikian, baik data observasi maupun angket indikator tekun menghadapi tugas sama-sama mengalami peningkatan dan telah mencapai kriteria minimal $75 \%$. Dalam pembelajaran Kooperatif tipe Numbered Heads Together, kelas menjadi lebih terkondisi bagi siswa untuk mau mengerjakan soal yang diberikan guru secara tuntas dengan sungguh-sungguh. Pada siklus I, terdapat 2 orang siswa yang hanya mengerjakan kurang dari $50 \%$ tugas yang diberikan. Namun pada siklus II, semua siswa telah mengerjakan dengan tuntas tugas yang diberikan, hanya satu orang siswa yang belum tuntas hanya mengerjakan lebih dari $50 \%$ dari tugas yang diberikan. Hal ini sejalan dengan pendapat Wina Sanjaya (2012: 249) bahwa pembelajaran ini dapat menambah kemampuan berpikir siswa, menemukan informasi dari berbagai sumber, dan belajar dari siswa yang lain sehingga siswa menjadi lebih tekun dalam mengerjakan tugas yang diberikan guru.

\section{b. Indikator ulet menghadapi kesulitan}

Skor pada siklus I menunjukkan bahwa indikator ulet menghadapi kesulitan hanya sebesar $74,11 \%$, ini menunjukkan bahwa indikator ulet menghadapi kesulitan masih tergolong rendah. Sedangkan pada siklus II indikator ulet menghadapi kesulitan meningkat menjadi $79,46 \%$, hal ini menunjukkan adanya peningkatan sebesar 5,35\%. Selain itu, data dari angket menunjukkan bahwa pada siklus I indikator ulet menghadapi kesulitan sebesar $74,40 \%$ dan pada siklus II mengalami peningkatan sebesar $3,58 \%$ menjadi $77,98 \%$. Berdasarkan pengamatan yang dilakukan selama proses pembelajaran dari siklus I dan siklus II, dapat dilihat bahwa pada siklus I sebagian besar siswa tidak bertanya kepada guru ketika mengalami kesulitan. Siswa lebih memilih untuk bertanya kepada teman daripada guru. Hal ini disebabkan karena siswa merasa lebih mudah memahami materi dengan bahasa yang digunakan temannya saat menjelaskan. Hal ini juga dikarenakan pada siklus I, materi yang diberikan sebagian besar bersifat teori dan sumber yang siswa miliki juga sudah tercakup materi yang diajarkan, sehingga siswa merasa tidak perlu untuk mengajukan pertanyaan terhadap materi. Pada siklus II memberikan pengaruh kepada siswa untuk bertanya kepada guru di mana soal yang harus dikerjakan siswa pada dasarnya dalam bentuk praktik dari aplikasi teori yang telah dipahami siswa sebelumnya. Selain itu, bentuk soal yang lebih aplikatif ternyata memberikan dampak terhadap keyakinan siswa untuk dapat menyelesaikannya dan bertanya kepada guru. Kesulitan yang dihadapi akan didiskusikan oleh kelompok tersebut kemudian apabila dalam diskusi belum ditemukan jawabannya, mereka akan berusaha untuk mencari pemecahannya dengan bertanya pada guru, sehingga keuletan siswa meningkat. Hal ini sesuai dengan komponen dalam pembelajaran kooperatif yaitu tugas kooperatif dan komponen struktur insentif kooperatif (Wina Sanjaya, 2012: 243). Tugas kooperatif berkaitan dengan hal yang menyebabkan siswa bekerja dalam menyelesaikan tugas kelompok; sedangkan struktur insentif kooperatif merupakan 
sesuatu yang membangkitkan motivasi siswa untuk bekerja sama mencapai tujuan kelompok.

\section{c. Indikator memiliki minat terhadap pelajaran}

Terjadi peningkatan skor pada indikator ini sebesar $8,04 \%$ dari data siklus I yaitu sebesar $82,14 \%$ ke siklus II menjadi sebesar 90,18\%. Selaras dengan data tersebut, pada angket terjadi peningkatan skor sebesar 2,08\%. Dengan diterapkannya pembelajaran Kooperatif tipe Numbered Heads Together mampu memberikan dampak positif terhadap suasana kelas yang terbangun. Adanya diskusi kelompok di dalamnya mampu menciptakan pembelajaran yang menarik, bermakna dan memberi tantangan sehingga siswa memiliki minat terhadap pembelajaran. Seperti yang diungkapkan Wina Sanjaya (2012: 250) bahwa interaksi selama pembelajaran berlangsung dapat meningkatkan motivasi. Hal ini dapat diwujudkan dengan memperhatikan penjelasan materi dari guru dan juga menyiapkan perlengkapan yang dibutuhkan selama pembelajaran.

\section{d. Indikator lebih senang bekerja mandiri}

Pada indikator ini terdapat peningkatan sebesar 3,13\% dari data siklus I yaitu sebesar $74,55 \%$ ke siklus II menjadi sebesar 77,68\%. Sedangkan data angket menunjukkan peningkatan sebesar $5,65 \%$ dari data siklus I yaitu sebesar 74,11\% ke siklus II menjadi sebesar 79,76\%. Pada dasarnya siswa memiliki tanggungjawab terhadap tugas yang diberikan pada dirinya. Hal ini ditunjukkan dengan adanya keinginan siswa untuk mempelajari materi secara mandiri dan menyelesaikan soal tersebut secara bersama-sama ketika di dalam kelompok. Namun ketika siswa sedang mengerjakan tes mandiri pada siklus I sebagian besar masih terlihat mencontek dan bertanya kepada temannya. Hal ini dikarenakan siswa tidak terbiasa dengan adanya tes baik sebelum maupun sesudah pelajaran, sehingga siswa terlihat kaget dan kurang mempersiapkan diri untuk memahami lebih dalam materi yang dipelajari. Namun pada siklus II mengalami peningkatan yang dikarenakan siswa sudah mulai menyesuaikan dengan pembelajaran yang dilaksanakan sehingga mereka sudah mempersiapkan diri khususnya untuk mengerjakan tes yang diberikan. Siswa mampu belajar mandiri di dalam kelompoknya tanpa terlalu tergantung pada penjelasan guru selama pembelajaran. Wina Sanjaya (2012: 246) mengemukakan bahwa keberhasilan kelompok tergantung pada setiap anggotanya, setiap anggota harus memberikan yang terbaik untuk keberhasilan kelompoknya. Pembelajaran ini dapat melatih tanggungjawab siswa dalam belajar. Dengan adanya tanggungjawab siswa dalam belajar, kemandirian siswa dalam belajar akan dapat ditingkatkan.

\section{e. Indikator cepat bosan pada tugas- tugas rutin}

Peningkatan sebesar $4,91 \%$ terjadi dari siklus I ke siklus II. Berdasarkan data angket yang diperoleh, terjadi kenaikan skor sebesar 1,79\%. Dari data yang diperoleh selama proses pembelajaran, siswa bersemangat dan antusias mengikuti pembelajaran dengan model pembelajaran yang baru. Ketika guru menyampaikan model pembelajaran yang akan digunakan pada saat awal kegiatan pembelajaran, sebagian besar siswa langsung menyiapkan perlengkapan pembelajaran. Dan siswa juga antusias saat berdiskusi dalam kelompoknya. Jika dilihat dari angket, sebagian besar menyatakan bersemangat belajar saat pembelajaran dilaksanakan dengan metode yang bervariasi. Pembelajaran dengan tipe ini memberi ruang dan kesempatan yang luas kepada 
setiap anggota kelompok untuk bertatap muka saling memberikan informasi dan saling membelajarkan (Wina Sanjaya, 2012: 247). Interaksi tatap muka siswa dengan siswa lain menjadi lebih efektif begitu pula interaksi siswa dengan guru menjadi lebih komunikatif. Kondisi ini memberikan dampak terhadap peningkatan semangat dan antusiasme siswa untuk mengikuti pembelajaran kemudian mereka tidak terjebak dengan kegiatan monoton dan mekanis dalam belajar.

\section{f. Indikator dapat mempertahankan pendapatnya}

Terjadi peningkatan skor dari siklus I sebesar 6,25\% ke siklus II. Dilihat dari data angket juga terjadi peningkatan skor sebesar $1,79 \%$. Berdasarkan data yang diperoleh selama proses pembelajaran dapat terlihat bahwa pada dasarnya siswa mengetahui dan mampu menjelaskan argumen atau alasan dari pekerjaan mereka. Selain itu jika terjadi perbedaan dalam mengerjakan soal, siswa akan berdiskusi dan berpendapat untuk membuktikan pendapat siapa yang benar. Pembelajaran NHT yang dilaksanakan selama di kelas membuat siswa memiliki pemahaman yang lebih karena selain dengan penjelasan lisan, siswa juga melakukan diskusi. Tidak hanya sampai diskusi selanjutnya siswa juga melakukan konfirmasi terhadap hasil diskusi pada akhir pembelajaran, sehingga siswa dapat menjawab pertanyaan yang ada dan memiliki argumen yang tepat atas jawaban tersebut. Sesuai dengan pendapat Wina Sanjaya (2012: 247) bahwa pembelajaran kooperatif melatih siswa untuk dapat mampu berpartisipasi aktif dan berkomunikasi dalam menyatakan ketidaksetujuan atau menyanggah pendapat orang lain. Dari sinilah siswa lebih mampu mempertahankan pendapatnya.

\section{g. Indikator tidak mudah melepaskan hal yang diyakini}

Diperoleh peningkatan skor sebesar $3,13 \%$ dari siklus I ke siklus II. Peningkatan dari data angket ditunjukkan sebesar 4,76\%. Siswa yakin dengan apa yang mereka pahami dan juga yakin dengan hasil pekerjaan mereka. Pada siklus I sebagian siswa masih ragu dalam mengutarakan pendapatnya. Hal ini dikarenakan siswa merasa takut salah dalam menjawab pertanyaan. Namun, guru selalu memberikan motivasi secara lisan kepada siswa untuk jangan takut salah karena ini adalah proses atau tahap pembelajaran. Sehingga, pada siklus II terjadi peningkatan terhadap keyakinan siswa dalam mengerjakan soal maupun saat mengutarakan pendapatnya. Pembelajaran ini merangsang siswa untuk mengembangkan gagasan dan ide-ide yang dianggapnya baik dan berguna (Wina Sanjaya, 2012: 247). Dari keyakinan siswa yang lebih tinggi dalam mengerjakan soal dapat memberikan pengaruh terhadap kemantapan siswa dalam mengutarakan pendapat ataupun dalam mengerjakan soalsoal karena pada dasarnya siswa telah mantap dengan yang diyakini sehingga tidak mudah untuk melepaskan yang mereka yakini itu.

\section{h. Indikator senang mencari dan memecahkan masalah soal-soal}

Terjadi peningkatan skor sebesar $10,27 \%$ dari siklus I ke siklus II. Selaras dengan data observasi, data angket juga menunjukkan adanya peningkatan skor sebesar 4,47\%. Pada siklus I, sebagian besar siswa tidak segera mengumpulkan tugas yang diberikan. Namun pada siklus II mengalami peningkatan di mana siswa tidak menunda-nunda lagi dalam mengumpulkan tugas. Hal ini dikarenakan saat diskusi siswa diberi waktu lebih lama dari siklus I, dan saat mengerjakan tes di siklus II siswa sudah lebih mempersiapkan 
diri sehingga mereka segera mengerjakan dan mengumpulkan tugas yang diberikan guru. Dari data angket juga diperoleh bahwa sebagian besar siswa menyatakan ingin mengerjakan soal Akuntansi yang lebih sulit jika sudah mampu mengerjakan soal yang mudah. Pembelajaran ini dapat mengembangkan kemampuan siswa untuk menguji ide dan pemahamannya sendiri, serta dapat berpraktik memecahkan masalah tanpa takut membuat kesalahan (Wina Sanjaya, 2012: 250). Individuindividu dalam kelompok tersebut tertantang untuk mengerjakan soal-soal yang memiliki tingkat kesulitan lebih tinggi karena dengan mereka bekerjasama soal yang tadinya cukup sulit jika harus dikerjakan sendiri menjadi lebih mudah dengan dikerjakan bersama-sama.

Dari pembahasan hasil penelitian mengenai Motivasi Belajar Akuntansi baik melalui observasi maupun angket dapat disimpulkan sama-sama mengalami peningkatan pada tiap indikatornya walaupun masih terdapat perbedaan skor pada keduanya. Hal ini disebabkan karena angket yang diberikan kepada siswa merupakan angket tertutup di mana siswa hanya mengisi salah satu dari alternatif yang disediakan sehingga alternatif yang dipilih siswa terkadang berbeda dengan yang terjadi ketika pembelajaran berlangsung. Beda halnya dengan observasi di mana peneliti sendiri yang melakukan pengamatan selama pembelajaran berlangsung di kelas berdasarkan indikator yang telah ditetapkan. Selain itu juga, waktu pengamatan dan pengisian angket yang berbeda juga memberikan pengaruh terhadap penilaian beberapa indikator motivasi belajar siswa. Pengisian angket yang dilakukan setelah kegiatan belajar mengajar berakhir memungkinkan siswa untuk segera mungkin menyelesaikan pengisian lembar angket tanpa terlebih dahulu memperhatikan butir-butir pernyataan. Walaupun demikian, perbedaan skor ini tidak banyak memberikan perbedaan hasil pada penelitian terkait Motivasi Belajar Akuntansi karena baik observasi maupun angket sama-sama mengalami peningkatan pada tiap indikator Motivasi Belajar Akuntansi siswa.

\section{Prestasi Belajar Akuntansi}

Data tes Prestasi Belajar Akuntansi dengan tipe NHT diperoleh dari nilai pre test dan nilai post test yang digunakan pada tiap siklus. Dari data yang diperoleh, dapat dilihat bahwa nilai rata-rata pre test dan post test siswa pada siklus I dengan menggunakan tipe NHT mengalami peningkatan sebesar 34,65. Pada siklus II, nilai rata-rata pre test dan post test siswa mengalami peningkatan sebesar 13,75. Selain itu, terdapat peningkatan prestasi belajar akuntansi siswa dari siklus I ke siklus II yang dilihat dari peningkatan post test sebesar 13,96 serta naiknya persentase ketuntasan siswa yang mencapai nilai KKM 75 dari $71,43 \%$ pada siklus I meningkat pada siklus II menjadi $100 \%$. Dari data yang diperoleh juga terlihat secara individu, prestasi belajar akuntansi siswa juga telah mengalami peningkatan dari siklus I ke siklus II.

\section{SIMPULAN DAN SARAN}

\section{Simpulan}

Berdasarkan hasil penelitian dan pembahasan dapat disimpulkan sebagai berikut:

a) Penerapan Model Pembelajaran Kooperatif Tipe Numbered Heads Together (NHT) dapat meningkatkan Motivasi Belajar Akuntansi Siswa Kelas X Akuntansi 1 SMK Negeri 1 Yogyakarta Tahun Ajaran 2013/2014. Hal tersebut didukung dengan data penelitian yang menunjukkan adanya peningkatan persentase skor Motivasi 
Belajar Akuntansi yang didapat melalui observasi dan angket.

b) Penerapan Model Pembelajaran Kooperatif Tipe Numbered Heads Together (NHT) dapat meningkatkan Prestasi Belajar Akuntansi Siswa Kelas X Akuntansi 1 SMK Negeri 1 Yogyakarta Tahun Ajaran 2013/2014. Hal tersebut didukung dengan data penelitian yang menunjukkan adanya peningkatan nilai rata-rata yang di lihat dari post test serta peningkatan persentase siswa yang telah mencapai KKM dari siklus I ke siklus II.

\section{Saran}

\section{a) Bagi guru}

Dalam pelaksanaan pembelajaran, guru sebaiknya menerapkan model pembelajaran yang bervariasi sehingga mampu meningkatkan motivasi dan prestasi belajar siswa. Guru dapat menerapkan Model Pembelajaran Kooperatif pada umumnya dan Tipe Numbered Heads Together (NHT) pada khususnya agar tercipta suasana belajar yang nyamandan tidak tegang sehingga motivasi dan prestasi siswa menjadi lebih optimal.

\section{b) Bagi Siswa}

Siswa perlu meningkatkan motivasi belajarnya, terutama keuletannya dalam belajar dengan tidak mudah putus asa dalam menghadapi kesulitan dalam belajar dan bertanya kepada teman dan guru saat mengalami kesulitan.

\section{DAFTAR PUSTAKA}

Dimyati \& Mudjiono. (2009). Belajar dan Pembelajaran. Jakarta: Rineka Cipta.
Djaali. (2012). Psikologi Pendidikan. Jakarta: Bumi Aksara.

Mohamad Nur. (2005). Pembelajaran Kooperatif. Surabaya: Pusat Sains dan Matematika Sekolah UNESA.

Muhibbin Syah. (2012). Psikologi Belajar. Jakarta: PT RajaGrafindo Persada.

Rochiati Wiriaatmadja. (2006). Metode Penelitian Tindakan Kelas untuk Meningkatkan Kinerja Guru dan Dosen. Bandung: PT Remaja Rosdakarya.

Sardiman AM. (2011). Interaksi dan Motivasi Belajar Mengajar. Jakarta: PT. Rajagrafindo Persada.

Sugiyono. (2012). Metode Penelitian Pendidikan. Bandung: Alfabeta.

(2012). Statistika untuk Penelitian. Bandung: Alfabeta.

Suharsimi Arikunto. (2012). Penelitian Tindakan Kelas. Jakarta: PT Bumi Aksara.

Wina Sanjaya. (2012). Strategi Pembelajaran Berorientasi Standar Proses Pendidikan. Jakarta: Kencana. 